УДК636.2.09:616.995.132-08:577.1:616.15

doi: $10.36359 /$ scivp.2019-20-2.18

\title{
ЗМІНИ БІОХІМІЧНИХ ПОКАЗНИКІВ КРОВІ ХВОРОЇ НА ТРИХУРОЗ ВЕЛИКОЇ РОГАТОЇ ХУДОБИ В ПРОЦЕСІ ЛІКУВАННЯ
}

\author{
T. С. Шевченко ${ }^{2}$ здобувач \\ Полтавська державна аграрна академія \\ вул. Г. Сковороди, 1/3, м. Полтава, 36003, Україна
}

Серед основних галузей, щзо забезпечують населення м'ясними та молочними продуктами, значна частка припадає на скотарство. Перешкодою для успішного виробництва продукиії иієї галузі є інвазійні захворювання великої рогатої худоби. Одним $з$ таких захворювань є трихуроз великої рогатої худоби. Це захворювання спричиняється круглими гельмінтами роду Trichuris, які локалізуються у товстому відділі кишечника $i$ призводять до анемії, виснаження, а інколи і до загибелі тварин. Тому детальне вивчення цьвого захворювання сприятиме розвитку молочного та м'ясного виробництва.

Дослідження проведені на теличках 6-12-ти місячного віку, хворих на трихуроз. У тварин досліджували зміни біохімічних показників сироватки крові у прочесі застосування лікарських засобів. Телиці були розділені на 5 груп: 4 дослідні і 5-та-контрольна. Тваринам 1-ї та 2-ї групи застосовували препарат промектин 1\% ін'єкиійний, першій групі одноразово, другій - дворазово, з інтервалом 24 години. 3-й та 4-й групі застосовували препарат альбентабс-360, внутрішньо. Третій групі-одноразово, четвертій-дворазово, з інтервалом 24 години. Кров відбирали до задавання препаратів на 5-й та 10-й день після останньої дачі npenapamy.

До задавання лікарських засобів у сироватці крові хворих тварин відмічали зниження вмісту загального білку, альбумінів, азоту, сечовини, креатиніну, глюкози, кальиію, ліпопротеїдів та каротину. Також відмічалося підвищення активності AcAm.

Встановлено, що на 5 добу після останнього застосування препаратів у сироватиі крові дослідних тварин вміст загального білку, альбумінів, креатиніну, кальцію, фосфору, ліпопротеїдів та каротину збільшився. Водночас спостерігалося зниження активності АсАт та АлАт у 1-й, 2-й та 4-й групах тварин, а у 3-й групі активність ферментів зросла.

На 10-й день після лікування, у 1-ц̌, 2-й та 4-й групах відмічали подальші зміни біохімічних показників у сторону збільшення. Показники в изих групах досягли рівня фізіологічних меж. У 3-й групі, за одноразового застосування альбентабсу 360, відмічали зниження вмісту загального білку, альбумінів, глобулінів, креатиніну, неорганічного фосфору, ліпопротеїдів та активності лужної фосфатази. Активність АсАт та АлАт знизилася у 1-й та 3-й групах, а у 2-й та 4-й-зросла.

Ключові слова: БІОХІМІЧНІ ПОКАЗНИКИ, ВЕЛИКА РОГАТА ХУДОБА, ПРОМЕКТИН, АЛЬБЕНТАБС, ТРИХУРОЗ.

Молочне скотарство - одна із стратегічних галузей тваринництва України, що визначає продовольчу безпеку держави, якість харчування населення та має високий експортний потенціал. Основна маса м'ясної та молочної продукції надходить від великої рогатої худоби. У м'ясному балансі країни яловичина і телятина займають більше $40 \%$. Молоко та молочні продукти є продовольчими товарами першої необхідності. Основними виробниками молока є сільськогосподарські підприємства [1].

\footnotetext{
${ }^{2}$ Науковий керівник - В. О. Євстаф’єва, доктор ветеринарних наук, професор
} 
Для багатьох господарств виробництво молока рентабельно. Однак прибутковим воно стає тільки при достатньо високій продуктивності дійного стада і високій якості молока. На ці фактори суттєво впливають паразитарні захворювання, зокрема трихуроз великої рогатої худоби, який поширений в багатьох країнах світу, таких як Молдова, Азербайджан, Афганістан, Великобританія, Росія, Білорусь та ін., а також по всій території України $[2,3,4,5,6,7]$.

Це захворювання призводить до зниження продуктивності корів, затримки росту молодняку, а при високій інтенсивності інвазії навіть до смерті на фоні виснаження та анемії. Статевозрілі трихуриси паразитують у товстому відділі кишечника великої рогатої худоби. Занурюючись тонким головним кінцем у слизову оболонку кишечника, паразити механічно подразнюють стінки кишківника, призводячи до діареї, анемії та виснаження тварин. В результаті господарства потерпають від збитків в результаті недоотримання продукції тваринництва та зниження якості сировини [8].

Проблематикою трихурозу жуйних займалися зарубіжні дослідники Магомедбеков У.А., 1953, Крючкова Е.Н., 1997, Пігіна С. Ю., 2007, Гареєв А. Г., 1983., Шамхалов М. В., 2011, Пасечник В. Є., 2000 [9,10,11,12,13,6], та в Україні не достатньо матеріалів досліджень 3 питань цього захворювання саме у великої рогатої худоби.

Тому вивчення терапевтичної ефективності та динаміки впливу лікарських препаратів на показники крові хворої на трихуроз великої рогатої худоби є першоосновою для ефективної боротьби з даним захворюванням та підвищенню продуктивності тварин.

Метою досліджень стало 3'ясувати вплив вітчизняних терапевтичних препаратів на біохімічні показники крові великої рогатої худоби при трихурозі.

Завданням досліджень стало визначити динаміку змін біохімічних показників крові хворих на трихуроз телиць протягом лікування, застосовуючи різні схеми використання лікарських засобів.

Матеріали і методи. Дослідження проводились в осінньо-зимовий період 2017-2018 років на базі наукової лабораторії паразитології кафедри паразитології та ветеринарносанітарної експертизи Полтавської державної аграрної академії. В умовах сільськогосподарського приватного підприємства «РВД-Агро» с. Червона Слобода, Черкаського району, Черкаської області, було сформовано 5 груп теличок 6-12-ти місячного віку, зі встановленим діагнозом - трихуроз, по 5 голів у кожній. Діагноз був встановлений попередньо за допомогою гельмінтоовоскопії згідно методу Трача В. Н. [14]. Першу групу формували хворі на трихуроз телички, яких лікували препаратом промектин 1\%, підшкірно, у дозі 1 мл на 50 кг маси тіла, одноразово. Другій групі задавали цей же препарат, в тій же дозі, але два дні підряд. Третій групі застосовували оральний препарат Альбентабс 360 в дозі 1 таблетка на 50 кг маси тіла, одноразово. Четверту групу формували хворі телиці, яким задавали альбентабс 360 у такій самій дозі, але два дні підряд. П’ята група - хворі, які не піддавалися лікуванню - контрольна. Всі тварини на період досліду перебували у однакових умовах утримання та годівлі. Кров на біохімічні дослідження відбиралася у кожної групи до застосування лікарських засобів, на 5 та 10-й день після останнього задавання препаратів. Проби крові піддавали центрифугуванню для відшарування сироватки. Готову сироватку крові відбирали та направляли на біохімічні дослідження у Науково-дослідний центр біобезпеки та екологічного контролю ресурсів АПК Дніпропетровського державного аграрноекономічного університету. Визначали кількість загального білку, альбуміни, глобуліни, білковий коефіцієнт, сечовину, азот сечовини, креатинін, АсАт, АлАт, АсАт/АлАт, лужну фосфатазу, глюкозу, кількість кальцію, фосфору, кальцієво-фосфорний баланс, ліпопротеїди та каротин. Статистичну обробку результатів та розрахунок вірогідності проводили за допомогою комп'ютерної програми Excel та таблиці критеріїв Ст'юдента. 
Результати й обговорення. Біохімічні показники клінічно здорових та хворих на трихуроз телиць до лікування представлені у таблиці 1.

Біохімічні показники сироватки крові хворих на трихуроз та клінічно здорових телиць до задавання препаратів

\begin{tabular}{|c|c|c|c|c|c|c|c|c|}
\hline \multirow[b]{3}{*}{ № } & \multirow[b]{3}{*}{ Показники } & \multirow{3}{*}{$\begin{array}{c}\text { Клінічно } \\
\text { здорові } \\
\text { телиці }\end{array}$} & \multicolumn{5}{|c|}{ Групи тварин (хворі телиці) } & \multirow{3}{*}{$\begin{array}{l}\text { Фізіоло } \\
\text { гічні } \\
\text { межі }\end{array}$} \\
\hline & & & \multirow[b]{2}{*}{ Контрольна } & \multicolumn{4}{|c|}{ Дослідні групи } & \\
\hline & & & & $\begin{array}{c}1 \\
\text { (промектин, } \\
1 \text { раз) }\end{array}$ & $\begin{array}{c}2 \\
\text { (промектин, } \\
2 \text { рази) }\end{array}$ & $\begin{array}{c}3 \\
\text { (альбентабс, } \\
1 \text { раз) }\end{array}$ & $\begin{array}{c}4 \\
\text { (альбентабс, } \\
2 \text { рази) }\end{array}$ & \\
\hline 1. & Заг. білок, г/л & $75,2 \pm 2,6$ & $64,8 \pm 4,2$ & $62 \pm 7,0$ & $60,7 \pm 5,9$ & $62,7 \pm 6,9$ & $60,3 \pm 5,7^{*}$ & $70-85$ \\
\hline 2. & Альбуміни, г/л & $44,6 \pm 1,5$ & $30 \pm 3,0^{* *}$ & $27,7 \pm 4,7 * *$ & $27,7 \pm 4,9 *$ & $26,3 \pm 4,9 * *$ & $28,3 \pm 5,4^{*}$ & $40-50$ \\
\hline 3. & Глобуліни, г/л & $32,6 \pm 0,6$ & $34,8 \pm 5,1$ & $34,3 \pm 9,3$ & $32,7 \pm 8,9$ & $33,7 \pm 9,9$ & $35,7 \pm 8,9$ & $25-41$ \\
\hline 4. & Білк. Коеф., од & $0,9 \pm 0,1$ & $0,98 \pm 0,2$ & $1 \pm 0,3$ & $0,93 \pm 0,2$ & $0,97 \pm 0,3$ & $1,2 \pm 0,2$ & $0,6-1,1$ \\
\hline 5. & Сечовин, ммоль/л & $3,7 \pm 0,3$ & $3,38 \pm 0,3$ & $3,57 \pm 0,5$ & $3,43 \pm 0,4$ & $3,77 \pm 0,4$ & $4,03 \pm 0,5$ & $3-6$ \\
\hline 6. & Азот сечов., мг\% & $8,4 \pm 0,4$ & $6,44 \pm 0,6^{*}$ & $6,8 \pm 0,9$ & $6,9 \pm 0,9$ & $7,37 \pm 0,8$ & $7,2 \pm 0,9$ & $8-14$ \\
\hline 7. & $\begin{array}{l}\text { Креатинін, } \\
\text { мкмоль/л }\end{array}$ & 10,6 & $1,3^{*}$ &, $6 * *$ & $0,4 * *$ & ** & $51,67 \pm 10,7^{* *}$ & 0 \\
\hline 8. & АсАт, Од/л & $37,2 \pm 2,6$ & $101 \pm 10^{* * *}$ & $94 \pm 14,8 * *$ & $93 \pm 14,8^{* *}$ & $95,67 \pm 15,1^{* *}$ & $95 \pm 15,0 * *$ & $10-50$ \\
\hline 9. & АлАт, Од/л & $28,8 \pm 1,6$ & $34,8 \pm 6,2$ & $30,3 \pm 8,9$ & $29,3 \pm 8,9$ & $32 \pm 8,5$ & $30 \pm 8,6$ & $10-30$ \\
\hline 10. & АсАт/АлАт, од. & $1,3 \pm 0,1$ & $3,1 \pm 0,3 * * *$ & $3,33 \pm 0,5^{* *}$ & $3,23 \pm 0,5^{* *}$ & $3,6 \pm 0,5^{* *}$ & $3,63 \pm 0,5 * *$ & $1,0-3,4$ \\
\hline & $\begin{array}{l}\text { Луж. } \\
\text { Од/л }\end{array}$ & $124 \pm 11,1$ & $105 \pm 15,5$ & $118 \pm 24,2$ & $103 \pm 13,8$ & 26,9 & $=27,7$ & 100-200 \\
\hline 12. & Глюкоза, ммоль/л & $2,8 \pm 0,1$ & $2,4 \pm 0,2$ & $2,38 \pm 0,3$ & $2,42 \pm 0,3$ & $2,42 \pm 0,3$ & $2,3 \pm 0,8$ & $2,5-3,5$ \\
\hline 13. & Са, ммоль/л & $2,8 \pm 0,1$ & $1,97 \pm 0,1 * * *$ & $1,9 \pm 0,1 * * *$ & $1,9 \pm 0,1$ & $1,2 \pm 0,1 * * *$ & $1,48 \pm 0,3 * *$ & $2,4-3,2$ \\
\hline 14. & Неорг.Р, ммоль/л & $1,8 \pm 0,1$ & $1,48 \pm 0,1$ & $1,5 \pm 0,2$ & $1,77 \pm 0,3$ & $1,77 \pm 0,3$ & $1,5 \pm 0,2$ & $1,5-2,2$ \\
\hline 15. & $\mathrm{Ca} / \mathrm{P}$, од. & $1,5 \pm 0,1$ & $1,34 \pm 0,1$ & $1,27 \pm 0,1$ & $1,53 \pm 0,2^{* * *}$ & $1,5 \pm 4,8$ & $1,07 \pm 0,1^{*}$ & $1,2-1,6$ \\
\hline 16. & $\begin{array}{l}\text { Ліпопротеїди } \\
\text { заг., мг\% }\end{array}$ & $514 \pm 71,7$ & $362 \pm 64,2$ & $285 \pm 61^{*}$ & $293 \pm 59,2 *$ & $288 \pm 60^{*}$ & $285 \pm 66,4^{*}$ & $400-800$ \\
\hline 17. & Каротин, мг\% & $352 \pm 25,3$ & $238 \pm 24,9^{*}$ & $247 \pm 44$ & $253 \pm 43$ & $250 \pm 46,5$ & $249 \pm 47,1$ & $275-965$ \\
\hline
\end{tabular}

Примітка: *- $\mathrm{P}<0,05, *_{\text {- }} \mathrm{P}<0,01$, ***- $\mathrm{P}<0,001$ - відносно показників клінічно здорових тварин.

Аналізуючи дані таблиці 1, до початку лікування у хворих тварин всіх груп була суттєво знижена кількість загального білку, альбумінів, азоту сечовини, креатиніну, глюкози, кальцію, каротину та ліпопротеїдів. Такі зміни в крові вказують на анемію в результаті порушення всмоктування поживних речовин у кишечнику в наслідок запальних процесів слизової оболонки кишківника, в зв'язку з механічним впливом паразитів, і як результат цього - виснаження тварин. На ряду з цими даними, спостерігається зашкалювання показників АсАт, що є результатом токсичного впливу продуктів життєдіяльності гельмінтів на організм хворих.

Результати біохімічних досліджень крові хворих телиць на п'ятий день після останньої дачі препарату представлені в таблиці 2.

Згідно з таблицею 2, на 5-й день після задавання лікарських засобів, у дослідних групах спостерігалося підвищення рівня загального білку на 26 \% (1 група) та 61 \% (3 група). В цих групах показники вийшли на рівень фізіологічної норми. В другій групі кількість загального білку зросла на 14 \%, а в четвертій 5 \%, та ці групи залишались 3 показниками нижчими фізіологічних меж. Кількість альбумінів у першій групі зросла на $83 \%$, у другій на 62\%, у третій на $125 \%$, у четвертій на 48 \%. Кількість глобулінів у другій та четвертій групі знизилась на 34 та 40 \%, відповідно, перетнувши рівень нижньої межі фізіологічної норми. Білковий коефіцієнт збільшився в усіх групах на 58-87 \%. 
Біохімічні показники сироватки крові хворої на трихуроз великої рогатої худоби на 5-й день після лікування

\begin{tabular}{|c|c|c|c|c|c|c|c|}
\hline \multirow{3}{*}{ № } & \multirow[b]{3}{*}{ Показники } & \multicolumn{5}{|c|}{ Групи тварин (хворі телиці) } & \multirow[b]{3}{*}{$\begin{array}{l}\text { Фізіоло- } \\
\text { гічні межі }\end{array}$} \\
\hline & & \multirow[b]{2}{*}{ Контрольна } & \multicolumn{4}{|c|}{ Дослідні групи } & \\
\hline & & & $\begin{array}{c}1 \\
\text { (промектин, } \\
1 \text { раз) }\end{array}$ & $\begin{array}{c}2 \\
\text { (промектин, } \\
2 \text { рази) }\end{array}$ & $\begin{array}{c}3 \\
\text { (альбентабс, } \\
1 \text { раз) }\end{array}$ & $\begin{array}{c}4 \\
\text { (альбентабс, } \\
2 \text { рази) }\end{array}$ & \\
\hline 1. & Заг. білок, г/л & $64 \pm 4,36$ & $78,3 \pm 7,13$ & $69,3 \pm 3,84$ & $101 \pm 5,49^{* * *}$ & $63,3 \pm 5,24$ & $70-85$ \\
\hline 2. & Альбуміни, Г/л & $31,6 \pm 4,22$ & $50,67 \pm 7,22$ & $45 \pm 0,58^{*}$ & $59,33 \pm 9,17^{*}$ & $42 \pm 2,64$ & $40-50$ \\
\hline 3. & Глобуліни, г/л & $34 \pm 4,89$ & $27,67 \pm 2,9$ & $24,3 \pm 3,93$ & $42 \pm 5,5$ & $21,33 \pm 2,67$ & $25-41$ \\
\hline & Білк. Коеф., од & $0,92 \pm 0,11$ & $1,87 \pm 0,31^{*}$ & $1,93 \pm 0,29 *$ & $1,53 \pm 0,40$ & $2 \pm 0,15^{* * *}$ & $0,6-1,1$ \\
\hline 5. & Сечовин, ммоль/л & $3,74 \pm 0,34$ & $2,2 \pm 0,4^{*}$ & $4,53 \pm 0,67$ & $3,93 \pm 0,68$ & $4,26 \pm 0,09$ & $3-6$ \\
\hline 6. & Азот сечов., мг\% & $6,54 \pm 0,81$ & $4,17 \pm 077$ & $8,63 \pm 1,28$ & $7,5 \pm 1,32$ & $8,13 \pm 0,18$ & $8-14$ \\
\hline 7. & Креатинін, мкмоль/л & $67,8 \pm 10,8$ & $99,67 \pm 7,51^{*}$ & $91,33 \pm 9,02$ & $126,33 \pm 8,45^{* *}$ & $82 \pm 20,67$ & $80-130$ \\
\hline 8. & АсАт, Од/л & $100,6 \pm 9,3$ & $91 \pm 15,27$ & $71,67 \pm 5,24^{*}$ & $130 \pm 16,02$ & $68,33 \pm 5,78^{*}$ & $10-50$ \\
\hline & АлАт, Од/л & $35 \pm 6,63$ & $26,3 \pm 4,48$ & $22,3 \pm 1,76$ & $35,7 \pm 4,63$ & $28,3 \pm 5,9$ & $10-30$ \\
\hline 10. & АсАт/АлАт, од. & $3,13 \pm 0,34$ & $3,5 \pm 0,05$ & $3,3 \pm 0,49$ & $3,67 \pm 0,12$ & $2,6 \pm 0,53$ & $1,0-3,4$ \\
\hline 11. & Луж. фосфатаза, Од/л & $103,8 \pm 15,14$ & $79,5 \pm 34,5$ & $137 \pm 8,5$ & $155 \pm 46,8^{*}$ & $93 \pm 10,1 * *$ & $100-200$ \\
\hline 12. & Глюкоза, ммоль/л & $2,32 \pm 0,20$ & $2,53 \pm 0,14$ & $2,27 \pm 0,09$ & $2,13 \pm 0,09$ & $2,43 \pm 0,18$ & $2,5-3,5$ \\
\hline 13. & Са, ммоль/л & $1,92 \pm 0,1$ & $2,47 \pm 0,12^{* *}$ & $2,27 \pm 0,17$ & $2,97 \pm 0,64$ & $2,07 \pm 0,2$ & $2,4-3,2$ \\
\hline 14. & Неорг.Р, ммоль/л & $1,46 \pm 0,14$ & $2,23 \pm 0,43$ & $2,33 \pm 0,12^{* *}$ & $2,6 \pm 0,3^{* *}$ & $2,13 \pm 0,07 * *$ & $1,5-2,2$ \\
\hline 15. & Са/Р, од. & $1,35 \pm 0,13$ & $1,17 \pm 0,13$ & $0,97 \pm 0,03 *$ & $1,13 \pm 0,12$ & $0,67 \pm 0,34$ & $1,2-1,6$ \\
\hline & $\begin{array}{l}\text { Лiпопротеїди заг., } \\
\text { мг\% }\end{array}$ & $361 \pm 66,14$ & $487 \pm 3,18$ & $560 \pm 78,87$ & $566 \pm 54,96^{*}$ & $530 \pm 30,46^{*}$ & $400-800$ \\
\hline 17. & Каротин, мг\% & $239 \pm 22,9$ & $376 \pm 14,5 * * *$ & $336 \pm 26,1^{*}$ & $346 \pm 6,33 * *$ & $334 \pm 40,3$ & $275-965$ \\
\hline
\end{tabular}
Примітка: *- $\mathrm{P}<0,05,{ }^{* *}$ - $\mathrm{P}<0,01,{ }^{* * *}$ - $\mathrm{P}<0,001 \quad$ - відносно показників контрольної групи.

У групах № 2, 3 та 4 підвищився рівень азоту сечовини на 25 \% у 2-й, на 2 \% у 3-й та на 13 \% у 4-й групі, а у першій знизився на 39 \%. Рівень креатиніну значно підвищився ( на 98, 91, 143 та 59\% відповідно) і досяг фізіологічних меж у всіх дослідних групах. Рівень АсАт та АлАт знизився у 1-й групі на 3 та $13 \%$, у 2-й групі на 23 та $24 \%$, у 4-й групі на 28 та $6 \%$. У 3 групі рівень АсАт та АлАт збільшився на 36 та 12 \%. У 1-й та 4-й групі спостерігалося суттєве зниження рівня лужної фосфатази (на 33 та 23 \%) до показників нижче фізіологічної норми. Рівень глюкози на 5-й день збільшився у 1-й та 4-й групі на 6 \%, а у 2-й та 3-й знизився на 6 та $12 \%$. Показники кальцію, фосфору, ліпопротеїдів та каротину зросли у всіх групах. Так, рівень кальцію у 1-й групі зріс на $30 \%$, у 2-й - на $42 \%$, у третій - на $147 \%$, у 4-й - на 40 \%. Показники фосфору у 1-й групі зросли на $49 \%$, у 2-й - на $32 \%$, у 3-й - на $49 \%$, у 4-й - на $42 \%$. Кількість ліпопротеїдів збільшилася у 1-й групі на $71 \%$, у 2-й - на $91 \%$, у 3-й - на 96 \%, у 4-й - на 86 \%. Рівень каротину зріс на 52 \% у 1-й групі, на 33 \% у 2-й групі, на 38 \% у 3-й групі і на 34 \% у 4-й. Такі дані свідчать про покращення всмоктування поживних речовин у організмі лікованих тварин.

Результати біохімічних досліджень крові на 10-й день після останньої дачі лікарських засобів представлені в таблиці 3.

На 10-й день після останньої дачі препарату, у 1-й групі рівень загального білка і альбумінів не змінився після попередніх досліджень і залишався в межах фізіологічної норми. Збільшилася кількість глобулінів на $5 \%$, сечовини на $83 \%$, азоту сечовини на $85 \%$, лужна фосфатаза зросла на $71 \%$, кількість фосфору підвищилася на $24 \%$, ліпопротеїдів на $27 \%$, в порівнянні з показниками на 5-й день після лікування. Знизилися у 1-й групі такі показники як АсАт (на $15 \%$ ) та АлАт (на 8 \%), що вказує на нормалізацію функції печінки. Незначно знизився рівень каротину - на $11 \%$. 
Біохімічні показники сироватки крові хворої на трихуроз великої рогатої худоби на 10 день після лікування

\begin{tabular}{|c|c|c|c|c|c|c|c|}
\hline \multirow[b]{3}{*}{ № } & \multirow[b]{3}{*}{ Показники } & \multicolumn{5}{|c|}{ Групи тварин (хворі телиці) } & \multirow{3}{*}{$\begin{array}{c}\text { Фізіологічн } \\
\text { і межі }\end{array}$} \\
\hline & & \multirow[b]{2}{*}{ Контрольна } & \multicolumn{4}{|c|}{ Дослідні групи } & \\
\hline & & & $\begin{array}{c}1 \\
(\text { промектин, } \\
1 \text { раз) }\end{array}$ & $\begin{array}{c}2 \\
\text { (промектин, } \\
2 \text { рази) }\end{array}$ & $\begin{array}{c}3 \\
(\text { альбентабс, } \\
1 \text { раз) }\end{array}$ & \begin{tabular}{|c}
4 \\
$($ альбентабс, \\
2 рази)
\end{tabular} & \\
\hline 1. & Заг. білок, г/л & $63,2 \pm 3,67$ & $78 \pm 4,51 *$ & $102 \pm 15,3^{*}$ & $62 \pm 4,04$ & $80 \pm 14,5$ & $70-85$ \\
\hline 2. & Альбуміни, г/л & $30,2 \pm 2,5$ & $50 \pm 4 * *$ & $66,33 \pm 6,49 * * *$ & $39 \pm 1,52 *$ & $54,67 \pm 9,17^{*}$ & $40-50$ \\
\hline 3. & Глобуліни, г/л & $34,6 \pm 4,78$ & $28 \pm 4,04$ & $36 \pm 8,96$ & $23 \pm 3,6$ & $25,33 \pm 5,36$ & $25-41$ \\
\hline 4. & Білк. Коеф., од & $1,06 \pm 0,2$ & $1,87 \pm 0,29 *$ & $2 \pm 0,32 *$ & $1,8 \pm 0,32$ & $2,2 \pm 0,11 * *$ & $0,6-1,1$ \\
\hline 5. & Сечовин, ммоль/л & $3,8 \pm 0,33$ & $4,03 \pm 1,04$ & $5,83 \pm 0,95$ & $4,67 \pm 1,02$ & $6,4 \pm 1,21$ & $3-6$ \\
\hline 6. & Азот сечов., мг\% & $6,42 \pm 0,76$ & $7,73 \pm 1,99$ & $11,13 \pm 1,82 *$ & $8,9 \pm 1,96$ & $12,23 \pm 2,30^{*}$ & $8-14$ \\
\hline 7. & Креатинін, мкмоль/л & $66,8 \pm 10,1$ & $94,67 \pm 7,79$ & $125 \pm 6,66$ & $77,33 \pm 8,95$ & $08,67 \pm 16,04^{*}$ & $80-130$ \\
\hline 8. & АсАт, Од/л & $104 \pm 9,4$ & $77,67 \pm 6,49 *$ & $109,33 \pm 11,78$ & $78,67 \pm 5,81$ & $83 \pm 12,50$ & $10-50$ \\
\hline 9. & АлАт, Од/л & $34,8 \pm 6,35$ & $24,3 \pm 2,4$ & $34,3 \pm 4,26$ & $22 \pm 1,53$ & $29,3 \pm 3,28$ & $10-30$ \\
\hline 10. & АсАт/АлАт, од. & $3,22 \pm 0,34$ & $3,2 \pm 0,2$ & $3,2 \pm 0,15$ & $3,6 \pm 0,05$ & $2,87 \pm 0,28$ & $1,0-3,4$ \\
\hline 11. & Луж. фосфатаза, Од/л & $103 \pm 14,68$ & $136 \pm 21,1$ & $229 \pm 24,4 * *$ & $124 \pm 4,91$ & $114 \pm 8,57$ & $100-200$ \\
\hline 12. & Глюкоза, ммоль/л & $2,34 \pm 0,17$ & $2,47 \pm 0,03$ & $2,4 \pm 0,11$ & $2,56 \pm 0,18$ & $2,3 \pm 0,06$ & $2,5-3,5$ \\
\hline 13. & Са, ммоль/л & $1,98 \pm 0,06$ & $2,43 \pm 0,26$ & $3,43 \pm 0,76$ & $1,97 \pm 0,03$ & $2,63 \pm 0,64$ & $2,4-3,2$ \\
\hline 14. & Неорг.Р, ммоль/л & $1,56 \pm 0,15$ & $2,77 \pm 0,26^{* *}$ & $3,63 \pm 0,32 * * *$ & $2,1 \pm 0,31$ & $2,93 \pm 0,45^{*}$ & $1,5-2,2$ \\
\hline 15. & $\mathrm{Ca} / \mathrm{P}$, од. & $1,3 \pm 0,12$ & $0,9 \pm 0 * *$ & $0,9 \pm 0,15$ & $0,97 \pm 0,14$ & $0,87 \pm 0,07 *$ & $1,2-1,6$ \\
\hline & $\begin{array}{l}\text { Ліпопротеїди } \\
\text { мг\% }\end{array}$ & $325 \pm 40,01$ & $620 \pm 87,13^{*}$ & $593 \pm 45,07 * *$ & $463 \pm 26,99 *$ & $582 \pm 93,40 *$ & $400-800$ \\
\hline 17. & Каротин, мг\% & $220 \pm 11,6$ & $336 \pm 43,5^{*}$ & $283 \pm 24,2 *$ & $354 \pm 31,3 * *$ & $328 \pm 26,8^{* *}$ & $275-965$ \\
\hline
\end{tabular}

Примітка: *- $\mathrm{P}>0,95$, **- $\mathrm{P}>0,99, * * *$ - $>>0,999$ - відносно показників контрольної групи.

У 2-й групі спостерігалося збільшення всіх показників, окрім каротину, рівень якого знизився на 16 \%. Кількість загального білку та альбумінів збільшилася на 47 \%, глобулінів на $48 \%$, сечовини на $29 \%$, азоту сечовини - на $22 \%$, креатинін підвищився на $37 \%$, лужна фосфатаза - на $67 \%$, глюкоза - на $6 \%$, кальцій - на $51 \%$, фосфор - на $56 \%$, ліпопротеїди - на 6 \%. В свою чергу, відмічалося підвищення рівня АсАт на 52 \% та АлАт на 54 \%. На нашу думку, це реакція печінки на збільшену кратність застосування препарату.

Непогані результати лікування також спостерігали у 4-й групі. Кількість загального білку зросла ще на $26 \%$, альбумінів на $30 \%$, глобулінів на $19 \%$, сечовини та азоту сечовини на $50 \%$, лужна фосфатаза збільшилася на $22 \%$, фосфор на 37, ліпопротеїди на $10 \%$. Також відзначили підвищення рівня АсАт на $21 \%$ та АлАт на $3 \%$, що можливо пов'язано 3 підвищенням навантаження на печінку в зв'язку з дворазовим застосуванням лікарських засобів. Креатинін та кальцій змінили свої значення в менший бік на 32 та 27 \%.

Найгірші дані біохімічних показників отримали у 3-й групі. Відмічали зниження кількості білку до початкових значень, що знаходилися поза фізіологічною нормою. Рівень альбумінів знизився на $34 \%$, глобуліни на $45 \%$, рівень креатиніну на $61 \%$, АсАт - на 3 9\%, АлАт - на 38 \%, неорганічний фосфор - на $19 \%$, ліпопротеїди на 18 \%. Збільшення спостерігалося показників сечовини та азоту сечовини на 19\%, глюкози - на 20 \%, кальцію на $34 \%$ і незначне (2\%) підвищення каротину, в порівнянні з показниками на 5-й день лікування. Такі результати ми пов'язуємо з низькою терапевтичною ефективністю альбентабсу 360 за одноразового застосування, адже після задавання цього препарату організм 60 -ти \% дослідних тварин цієї групи не звільнився від гельмінтів роду Trichuris. 


\title{
В И С Н О В К И
}

1. За трихурозу великої рогатої худоби встановлено зниження вмісту загального білку, альбумінів, азоту сечовини, креатиніну, глюкози, кальцію, ліпопротеїдів і каротину. Одночасно відмічене підвищення активності АсАт, що пояснюється токсичним впливом паразитів на організм хворих тварин.

2. На 5-й день після останнього застосування препаратів встановлено у всіх дослідних групах підвищення вмісту загального білку, альбумінів, креатиніну, кальцію, фосфору, ліпопротеїдів та каротину. Такі результати вказують на позитивну динаміку одужання тварин. Вміст сечовини зменшився у 1-й групі тварин, вміст азоту, сечовини та активність лужної фосфатази знизилися у 1-й та 4-й групі. Активність АсАт та АлАт зменшилася у 1, 2 та 4 групах і зросла у тварин 3-ої групи.

3. На 10-й день після лікування, у тварин 1-ї групи вміст загального білку та альбумінів залишився незмінним від попереднього дослідження та відповідав рівню фізіологічних меж. У 2-й та 4-й групах тварин показники вмісту білку і альбумінів підвищилися, а у тварин 3-ої групи ці показники знизилися до значень, які реєстрували на початку лікування.

4. $\quad$ Водночас з позитивною динамікою біохімічних показників у дослідних тварин 1-ої, 2-ої, 4-ої групах, у 3-й групі тварин на 10-у добу досліджень відмічали зниження вмісту глобулінів на 45 \%, креатиніну на 61 \%, лужної фосфатази на 20 \%, неорганічного фосфору на $19 \%$ та ліпопротеїдів на $18 \%$.

Перспективи досліджень. Планується з'ясувати стійкість яєць збудника трихурозу у зовнішньому середовищі до дії вітчизняних дезінфектантів.

\section{BIOCHEMICAL PARAMETERS OF BLOOD OF THE PATIENT'S TRICHURIS CATTLE IN THE COURSE OF TREATMENT}

\author{
T. S. Shevchenko \\ Poltava State Agrarian Academy \\ 1/3, Skovorody str., Poltava, 36003, Ukraine
}

S U M M A R Y

Among the main sectors that provide the population with meat and dairy products, a large share falls on cattle breeding. An obstacle to the successful production of this industry is invasive bovine disease. One of these diseases is trichurosis of cattle. This disease is caused by roundworms of the genus Trichuris, which are localized in the thick intestine and lead to anemia, exhaustion, and sometimes even death of animals. Therefore, a detailed study of this disease will contribute to the development of dairy and meat production.

The studies were conducted on 6-12 month-old donkeys, patients with trichyrosis. Animals studied changes in biochemical parameters of serum in the process of use of drugs. The heifers were divided into 5 groups: 4 experimental and 5-th - control. Animals of the 1st and 2nd groups used the drug promectin $1 \%$ injection, the first group once, the second - twice, at intervals of 24 hours. The 3rd and 4th groups used the preparation albentabs-360, internally. The third group - one time, the fourth - twice, at intervals of 24 hours. The blood was taken until the drug was prescribed on the 5th and 10th day after the last dose of the drug.

Before prescribing drugs in blood serum sick animals, there was a decrease in the content of total protein, albumin, nitrogen, urea, creatinine, glucose, calcium, lipoproteins and carotene. Also noted was an increase in the activity of AsAt. 
It was found that on the 5th day after the last application of serum products in experimental animals, the content of total protein, albumin, creatinine, calcium, phosphorus, lipoprotein and carotene increased. At the same time, there was a decrease in the activity of AsAt and AlAt in the 1st, 2nd and 4th groups of animals, and in the 3rd group the enzyme activity increased.

On the 10th day after treatment, in the 1 st, 2 nd and 4 th groups, further changes in biochemical parameters were noted in the direction of increase. Indicators in these groups have reached the level of physiological limits. In the 3rd group, with a single dose of albentable 360 , there was a decrease in the content of total protein, albumin, globulin, creatinine, inorganic phosphorus and lipoprotein in the activity of alkaline phosphatase. The activity of AsAt and AlAt decreased in $1 \mathrm{st}$ and 3rd groups, while in the 2nd and 4th groups it has increased.

Keywords: BIOCHEMICAL INDICATORS, CATTLE, PROMECTIN, ALBENTABS, TRICHUROSIS.

\title{
ИЗМЕНЕНИЯ БИОХИМИЧЕСКИХ ПОКАЗАТЕЛЕЙ КРОВИ БОЛЬНОГО ТРИХУРОЗОМ КРУПНОГО РОГАТОГО СКОТА В ПРОЦЕССЕ ЛЕЧЕНИЯ
}

\author{
T. С. Шевченко
}

Полтавская государственная аграрная академия

ул. Г. Сковороды, 1/3, г. Полтава, 36003, Украина

\section{А Н Н О Т А ЦИ Я}

Среди основных отраслей, обеспечивающих население мясными и молочными продуктами, значительная доля приходится на скотоводство. Препятствием для успешного производства продукции этой отрасли является инвазионные заболевания крупного рогатого скота. Одним из таких заболеваний является трихуроз крупного рогатого скота. Это заболевание вызывается круглыми гельминтами рода Trichuris, которые локализуются в толстом отделе кишечника и приводят к анемии, истощению, а иногда и к гибели животных. Поэтому детальное изучение этого заболевания способствует развитию молочного и мясного производства.

Исследования проведены на телочках 6-12-ти месячного возраста, больных трихурозом. У животных исследовали изменения биохимических показателей сыворотки крови в процессе применения лекарственных средств. Телки были разделены на 5 групп: 4 опытные и 5-я - контрольная. Животным 1-й и 2-й группы применяли препарат промектин 1\% инъекционный, первой группе единовременно, второй - двукратно, с интервалом 24 часа. 3-й и 4-й группе применяли препарат альбентабс-360, внутренне. Третьей группе - однократно, четвертой - двукратно, с интервалом 24 часа. Кровь отбирали до назначения препаратов, на 5 й и 10-й день после последней дачи препарата.

До назначения лекарственных средств в сыворотке крови больных животных отмечали снижение содержания общего белка, альбуминов, азота, мочевины, креатинина, глюкозы, кальция, липопротеидов и каротина. Также отмечалось повышение активности АсАт.

Установлено, что на 5 сутки после последнего применения препаратов в сыворотке крови опытных животных содержание общего белка, альбуминов, креатинина, кальция, фосфора, липопротеидов и каротина увеличилось. Одновременно наблюдалось снижение активности АсАт и АлАт в 1-й, 2-й и 4-й группах животных, а в 3-й группе активность ферментов возросла.

На 10-й день после лечения, в 1-й, 2-й и 4-й группах отмечали дальнейшие изменения биохимических показателей в сторону увеличения. Показатели в этих группах достигли уровня физиологических границ. В 3-й группе, за одноразового применения альбентабса 360, 
отмечали снижение содержания общего белка, альбуминов, глобулинов, креатинина, неорганического фосфора, липопротеидов и активности щелочной фосфатазы. Активность АсАт и АлАт снизилась в 1-й и 3-й группах, а во 2-й и 4-й - выросла.

Ключевые слова: БИОХИМИЧЕСКИЕ ПОКАЗАТЕЛИ, КРУПНЫЙ РОГАТЫЙ СКОТ, ПРОМЕКТИН, АЛЬБЕНТАБС, ТРИХУРОЗ.

\section{Л I T E P A T У P A}

1. Smith H. J. A clinical outbreak of Trichuris discolor infection in stabled calves / H. J. Smith, R.G. Stewenson // Can. Vet. J. - 1970. - V. 11, N 1. - P. 102-104.

2. Cercel I. Oesophagostomum, Chabertia and Trichocephalus species in sheep in Moldova / I. Cercel // Rev. Romano de Parasitol. - 2002. - V. 12, N 2. - P. 27.

3. Петров A. М. Гельминтофауна крупного рогатого скота, буйволов и зебу в Азербайджане. / А. М. Петров, М. К. Джавадов, Т. С. Скарбилович // Тр. Аз. НИВИ. - 1935. № 2. - С. 5-19.

4. Barus A. Nematodes parasitizing domestic ruminants in Afghanistan / A. Barus, A. Amin, K. Blazek, F. Moravec // Folia Parasitol. - Praha. -1976.-V. 23, N3. - P. 207-216

5. Hinks M.I A new record of the occurrence of Trichuris skrjzbini Baskakow, 1924 in sheep in Britain. / M.I. Hinks, R.J. Thomas // J. Helminthol. -1974.-V. 48, N1.-P. 33-38.

6. Пасечник B. E. Эколого-эпизоотологические основы профілактики трихоцефалеза овец в республике Молдова [Текст]: дис. ... канд. вет. наук / Пасечник В. Е. - Москва, 2000. $195 \mathrm{c}$.

7. Бобкова А. Ф. Гельминтофауна домашних жвачных и свиней зоны Белорусского Полесья: Автореф. дис. .канд. вет. наук. / Бобкова А.Ф. - Минск, 1956. - 21 с.

8. Clinical and therapeutic studies on parasitic gastroenteritis in sheep. / E.M. Shawkat, M.M. Abdel-Halim, A.A. Kubesy et al. // Vet. Med. J. Giza. - 1991. - V. 39, N 2. - P. 237-254.

9. Магомедбеков У. А. Распространение трихоцефал у овец в Дагестане. / У.А. Магомедбеков // Труды ин-та животноводства. - Махачкала. - 1956.- т. 3.- С. 77-79.

10. Крючкова E. H. Трихоцефалез жвачных животных в Центральном районе Нечерноземной зоны Российской Федерации (эризоотология, патогенез, лечение): автореф. дис. ...канд. вет. наук: 03.00.19 / Крючкова Е. Н.; Ивановс. Гос. Сельхоз. Академия. - Иваново, 1997. - 36 с.

11. Пигина С. Ю. Эпизоотология трихоцефалеза крупного рогатого скота в условиях Северного Кавказа и разработка оптимальных доз антигельминтиков: диссертация... кандидата ветеринарных наук: 03.00.19 / Пигина С. Ю.; Всерос. науч.-исслед. ин-т гельминтологии им. К.И. Скрябина. - М., 2007. - 152 с.

12. Гареев Альтаф Галиаскарович. Трихоцефалез овец и разработка рациональных мер борьбы с ним в условиях Башкирского Южного Урала (эпизоотология, патогенез, клиническая картина, терапия и профилактика): автореф. дис. ...канд. вет. наук: 03.00.20 / Гареев Альтаф Галиаскарович. - Уфа, 1983. - с. 233.

13. Шамхалов M. B. Трихоцефалез овец и коз в Прикаспийском регионе (эпизоотология и биология возбудителей) и совершенствование мер борьбы: автореф. дис. ...канд. вет. наук: 03.02.11 / М. В. Шамхалов. - Махачкала, 2011.- с. 155.

14. Трач В. Н. Рекомендации по применению нового метода учета яиц гельминтов и цист простейших в фекалиях животных [Текст]. / В. Н. Трач. - Киев, 1992. - 13 с.

\section{References}

1. Smith H. J. A clinical outbreak of Trichuris discolor infection in stabled calves. Can. Vet. J., 1970, V. 11, N 1., pp. 102-104. 
2. Cercel I. Oesophagostomum, Chabertia and Trichocephalus species in sheep in Moldova. Rev. Romano de Parasitol, 2002, V. 12, N 2, pp. 27.

3. Petrov A.M., Javadov M.K., Skarbilovich T. S. The helminthofauna of cattle, buffalo and zebu in Azerbaijan. Tr. Az. NIVI., 1935, № 2, pp. 5-19.[in Russian]

4. Barus A., Amin A., Blazek K., Moravec F. Nematodes parasitizing domestic ruminants in Afghanistan. Folia Parasitol, Praha, 1976, V. 23, N3, pp. 207-216.

5. Hinks M.I., Thomas R.J. A new record of the occurrence of Trichuris skrjzbini Baskakow, 1924 in sheep in Britain. J. Helminthol, 1974, V. 48, N1, pp. 33-38.

6. Pasechnik V.E. Ecological and epizootological foundations of the prevention of trichocephalosis of sheep in the Republic of Moldova [Text]: dis. ... Cand. wet Sciences. Moscow, 2000, pp.195. [in Russian]

7. Bobkova A.F. Helminthofauna domestic ruminants and pigs of the Belarussian Polesie zone: Author's abstract. dis. .cand. wet sciences. Minsk, 1956, pp. 21. [in Russian]

8. Shawkat E.M., Abdel-Halim M.M., Kubesy A.A et al. Clinical and therapeutic studies on parasitic gastroenteritis in sheep. Vet. Med. J., Giza, 1991, V. 39, N 2, pp. 237-254.

9. Magomedbekov U.A. Distribution of trichocephalus in sheep in Dagestan. Works in-that of animal husbandry, Makhachkala, 1956, pp. 77-79. [in Russian]

10. Kryuchkova, E.N. Trichocephalosis of ruminant animals in the Central Region of the Nonchernozem Zone of the Russian Federation (episotology, pathogenesis, treatment): Author. dis. ... Cand. wet Sciences: 03.00.19. Ivanovs. State Agricultural. Academy, Ivanovo, 1997, pp. 36. [in Russian]

11. Pigina S. Yu. Epizootology of cattle trichocephalosis in the North Caucasus and the development of optimal doses of anthelmintics: dissertation ... Candidate of Veterinary Sciences: 03.00.19. All-Russia. Nauch.-issled. in-t helminthology them. K.I. Scriabin, M., 2007, 152 pp. [in Russian]

12. Gareev Altaf Galiaskarovich. Trichocephalosis of sheep and the development of rational measures to combat it in the conditions of the Bashkir Southern Urals (epizootology, pathogenesis, clinical presentation, therapy and prevention): author. dis. ... Cand. wet Sciences: 03.00.20. Ufa, 1983, pp. 233. [in Russian]

13. Shamkhalov M.V. Trichocephalosis of sheep and goats in the Caspian region (epizootology and biology of pathogens) and the improvement of control measures: author. dis. ... Cand. wet Sciences: 03.02.11. Makhachkala, 2011, pp. 155. [in Russian]

14. Trach V.N. Recommendations for the use of a new method for recording helminth eggs and protozoan cysts in animal feces [Text]. Kiev, 1992, pp. 13. [in Russian].

Рецензент - А. Ф. Курман, к. біол. н., доцент, Інститут свинарства і АПВ НААН України. 